http://dx.doi.org/10.18778/7969-407-5.03

Christophe Swinarski*

\title{
Kadr normatywny immunitetu jurysdykcyjnego państwa w prawie międzynarodowym (w kontekście Europejskiej Konwencji Praw Człowieka)
}

\author{
Na cóż czekamy, zebrani na rynku? \\ Dziś mają przyjść barbarzyńcy. \\ Dlaczego taka bezczynność w senacie? \\ Senatorowie siedzą - czemuż praw nie uchwalą? \\ (...) \\ Czemu retorzy świetni nie przychodzą, jak zwykle, \\ by wygłaszać oracje, które ułożyli? \\ Dlatego że dziś mają przyjść barbarzyńcy, \\ (...) \\ a ich nudzą deklamacje i przemowy. \\ Wszyscy do domu wracają zamyśleni. \\ (...) \\ I ktoś, co właśnie wrócił od granicy, \\ mówi że już nie ma żadnych barbarzyńców.
}

Bez barbarzyńców - cóż poczniemy teraz? Ci ludzie byli jakimś rozwiązaniem.

Konstandinos Kawafis, Ekdota Poiemata, thum. Zygmunt Kubiak, 1904

* Konsultant międzynarodowy ds. prawa humanitarnego i praw człowieka, visiting professor Uniwersytetu La Plata (Argentyna), b. doradca prawny Międzynarodowego Komitetu Czerwonego Krzyża (MKCK). Autor dziękuje Panu dr. Michałowi Balcerzakowi i Panu mgr. Maciejowi Żenkiewiczowi z WPiA Uniwersytetu Mikołaja Kopernika za cenną pomoc w przygotowaniu tego tekstu. 


\section{Uwagi wstępne}

Ponawiając wyrazy wdzięczności za przywilej zaproszenia do udziału w tej Konferencji Grupy Polskiej Stowarzyszenia Prawa Międzynarodowego, chciałbym pogratulować Organizatorom szczęśliwej, bo precyzyjnej definicji jej tematu. Propozycja dyskusji o immunitetach „mających swoje źródło w prawie międzynarodowym" pozwala jasno określić ramy naszego spotkania, a szczególnie miejsce, jakie winna w nim zając kwestia immunitetu jurysdykcyjnego państwa w perspektywie prawa publicznego - temat, który nierzadko prowadzi do nieporozumień pojęciowych i pochopnych wniosków, przede wszystkim - jak się wydaje $-\mathrm{z}$ dwóch powodów.

Pierwszym z nich i niewątpliwie najważniejszym są rozbieżności co do koncepcji państwa pod kątem jego suwerenności i wynikająca z nich niejednolitość określania obszaru jego podmiotowości w porządku prawnym innego państwa, ze wszystkimi konsekwencjami w dziedzinach, w których pojawiają się zagadnienia stosunku prawa międzynarodowego do prawa wewnętrznego.

Drugim, związanym z poprzednim, zdaje się być traktowanie immunitetu państwa jako problemu zwłaszcza procesowego, pojawiającego się w momencie kolizji interesów prawnych podmiotów pochodzących ze zróżnicowanych formalnie porządków prawnych, a nie jako konstrukcji (instituto propio iure) prawa międzynarodowego. Aby uniknąć wynikających z tych powodów komplikacji merytorycznych i metodologicznych, chciałbym ograniczyć moje uwagi do określenia miejsca immunitetu jurysdykcji państwa w aktualnej topografii prawa międzynarodowego, nie wchodząc - bardziej niż okaże się to niezbędne - w związane $\mathrm{z}$ tematem kontrowersje ${ }^{1}$.

Kwestia uzasadnienia immunitetu państwa w prawie międzynarodowym pojawia się tam od zarania jego wyodrębnienia jako systemu normatywnego ze względu - słowami Komisji Prawa Międzynarodowego - iż „(...) dotyczy ona Państw w dwojaki sposób: z jednej strony jako suwerenów terytorialnych w wykonywaniu władzy nad wszystkimi elementami swego terytorium i z drugiej, jako obcych suwerenów, kiedy są ścigane przez inne podmioty, osoby fizyczne przed sądami lub organami administracyjnymi innego Państwa, którego kompetencja terytorialna rozszerza się na sprawy tyczące się państw obcych" ". Taki punkt wyjścia wiąże istnienie immunitetu państwa niemal wyłącznie z jego suwerennością terytorialną, nie uwzględniając innych pojęć prawa międzynarodowego.

${ }^{1}$ Zob. np. uwagi A. Wyrozumskiej, Polskie sady wobec immunitetu państwa obcego, PiP 2000, z. 649, s. 25.

2 Annuaire de la Commision du Droit International ACDI, 1978, vol. II, cz. II, rozdz. 13, s. 171 (tłum. autora). 
Tym niemniej już w 1950 r. Sir Hersch Lauterpacht mógł stwierdzić, że ,„prawo międzynarodowe, które tak znakomicie nalegało na szacunek należny jednemu suwerennemu Państwu przez drugie, odtąd przyznaje suwerenne prawa człowiekowi. Bo podstawowe prawa człowieka są nadrzędne wobec prawa suwerennego państwa"3. Nic więc dziwnego, że w obecnie obowiązującym prawie międzynarodowym zasadnicze zmiany strukturalne społeczności międzynarodowej i ich skutki co do natury prawnej immunitetu państwa musiały doprowadzić do różnic w pojmowaniu jego natury i obszaru obowiązywania ${ }^{4}$.

\section{Kadr prawa zwyczajowego}

Konfiguracja semantyczna immunitetu państwa jest zawarta w ogólnej definicji immunitetu ${ }^{5}$, jako: ,wolności jednego od władzy lub kontroli prawnej drugiego co do jakiegoś stosunku prawnego" ". W zwyczaju międzynarodowym pojawia się od początku jako prawna konsekwencja zasady suwerennej równości państw (par in parem non habet imperium) i jako taka została przyjęta w orzecznictwie

${ }^{3}$ H. Lauterpacht, International Law and Human Rights, Stevens, London 1950, s. 70 (thum. autora). Zob. idem, The Grotian Tradition of International Law, BYIL 1946, vol. 23, s. 1-53; idem, The Law of Nations, the Law of Nature and the Rights of Man, Transactions of the Grotius Society, 1943, vol. 29, s. 21-31.

${ }^{4}$ Zob. np. dictum lorda Binghama: „A State is either immune or it is not. There is no halfway and no scope for discretion”; zob. dictum lorda Milletta: „(...) State immunity is not a self-imposed restriction of its courts (...) chosen as a matter of discretion, relax or abandon. It is imposed by international law (podkr. C. S.) without any discrimination between the State or another", odpowiednio pkt 33 i pkt 101 w wyroku United Kingdom House of Lords (UKHL) 26, 2007, w sprawie James Mitchell v. Ministry of Interior of Kingdom of Saudi Arabia \& Lt. Col Abdul Aziz, obecnie przed ETPC (skarga nr 34356/06 I 40528/06), również A. Orakhelashvili, State Immunity \& Hierarchy of Norms: Why The Lords got it wrong, EJIL 2008, vol. 18, s. 955.

${ }_{5}$ Zob. ogólnie inter alia: J. Bröhmer, State Immunity and the violation of Human Rights, The Hague 1997; L. Caflisch, Immunités de juridiction et respect des droits de l'homme, [w:] L. Boisson de Chazournes \& V. Gowlland-Debbas (red.), L'ordre juridique international en quête d'équité et d'universalité, Liber Amicorum Geoges Abi Saab, La Haye, Londres, Boston 2001; J. Candrian, L'immunité des Etats face aux Droits de l'Homme et à la protection des biens culturels, Zurich, Bále, Genève 2005; M. Cosnard, La soumission des États aux tribunaux internes (Face à la théorie des immunités des Etats), Publications de RGDIP, Pédone 1996; E. Denza, Diplomatic Law. A Commentary on the Vienna Convention on Diplomatic Relations, wyd. 3, Oxford 2008; I. Pingel-Lenuzza, Les immunités des etats en droit international, Bruxelles 1998.

${ }^{6}$ S. Hohfeld, Jural Opposites, London 2001, s. 51:,,an immunity is one's freedom from the legal power and control of another as regards some legal relations"; także H. Fox, The Law of State Immunity, wyd. 2, Oxford 2008, s. 47-51; T. Meron, Human Rights and Humanitarian Norms as Customary Law, Oxford 1989; O. Schachter, The Decline of Nation-State and its Implications for International Law, „Columbia Journal of Transnational Law” 1997, vol. 36, s. 22. 
prawa wewnętrznego. W prawie zwyczajowym należy ona do jego korpusu normatywnego, a nie tylko zwykłej comitas gentium ${ }^{7}$. Jej pojmowanie w tym prawie ewoluowało wraz z przekształceniami percepcji konceptu suwerenności i jej konsekwencji.

$\mathrm{W}$ trakcie tej ewolucji immunitety prawa międzynarodowego różnie poszukiwały swego uzasadnienia normatywnego (ratio legis lub rationale według terminologii anglosaskiej), bo ,jeśli prawo międzynarodowe istnieje, dynamika suwerenności państwowej może być wyrażana w terminach prawnych i, jako że państwa są między ,sobą równe jako podmioty prawa, suwerenność wyraża w najwyższym stopniu ich stosunek do innych państw (i do międzynarodowych organizacji rządowych) określony tak, jakim go określa prawo"».

Jest więc zrozumiałe, że zwyczajowa konstrukcja immunitetów państwa przechodziła te same fazy legitymacji normatywnej co sam koncept suwerenności: od ponadnaturalnego pochodzenia władzy z jej absolutnym immunitetem osobistym i ogólnym (king can do no wrong), poprzez koncepcję patrymonialną (władca jako wyłączny właściciel państwa posiada suprema potestas) i koncepcję eksterytorialności jako główne uzasadnienie immunitetu suwerennego państwa, wykluczające jakąkolwiek interwencję organów innego państwa, tzn. w formie immunitetu absolutnego.

Zgodzić się tu trzeba, że to relacja między ewoluującym podejściem do konsekwencji suwerenności absolutnej w stosunkach międzynarodowych a potrzebą delimitacji i zrównoważenia konfliktów między suwerennościami jest przyczyną przeobrażeń w konstrukcji państwowego immunitetu jurysdykcyjnego ${ }^{9}$. Owa relacja między rozwijającą się i coraz to bardziej wielopłaszczyznową działalnością państwa w obrocie międzynarodowym leży w każdym razie u podłoża coraz szerszego przyjmowania jako zasady ograniczonego (restrictive) charakteru tego immunitetu.

Jako modus operandi tej ewolucji (praktycznie synchronicznej z przechodzeniem od koncepcji suwerenności absolutnej do koncepcji suwerenności

${ }^{7}$ Choć comitas gentium może być uważana za integralną część zwyczaju międzynarodowego, a nawet wręcz za synonim prawa międzynarodowego; zob. np. J. Sandorski, Opieka dyplomatyczna a międzynarodowa ochrona praw człowieka, Poznań 2006, s. 314.

${ }^{8}$ I. Brownlie, Principles of Public International Law, wyd. 6, Oxford 2003, s. 287; także zob. np. Dicta lordów Browne-Wilkinsona i Huttona w sprawie Pinocheta III, s. 14 i s. 62-63; orzeczenie Sędziego Marshalla w sprawie The Schooner Exchange v. McFadden \& others z 1812, 11 US (7 Cranch) 116; wyrok Sądu Apelacyjnego Paryża z 1894 w sprawie Ville de Genève v. matżonkowie Civry (sukcesja Księstwa Brunszwiku), „Journal de Droit International Privé” 1894, s. 1032.

${ }^{9}$ Zob. M. Koskenniemi, From Apology to Utopia - The Structure of International Legal Argument, Helsinki 1989, s. 933; Choć zdaniem I. Brownlie problem równowagi między konfliktami suwerenności nie daje się sprowadzić do dychotomii „,absolutny” v. „ograniczony immunitet”, zob. I. Brownlie, op. cit., s. 326. 
funkcjonalnej) pojawiła się konieczność rozróżnienia między państwem działającym de iure negotii a państwem w zakresie jego działalności de iure imperii. Działanie w stosunkach międzynarodowych państwa handlującego (état commerçant) wzrosło tak znacznie, iż klasyczny moduł normatywny prawa międzynarodowego stał się, operatywnie i normatywnie, nieprzydatny do rozwiązywania powstających problemów za pomocą klasycznych konceptów struktury stosunków międzynarodowych ${ }^{10}$. Nie od rzeczy jest tu zauważyć, że i w tej dziedzinie ewolucja od zasad absolutnego do restrykcyjnego konceptu immunitetu państwa odbywała się sposobem stopniowego przystosowania jego funkcji do zadań osiągnięcia w prawie koniecznej skuteczności, a więc na zasadach kryterium efektywności, które już Grocjusz uważał za podstawowe ${ }^{11}$.

Często przywoływanym dowodem na konceptualnie wykształcony zwyczajowy charakter immunitetu jurysdykcji jest tzw. Tate Letter (z 19 maja 1952 r.), w którym ówczesny Doradca Prawny Departamentu Stanu w liście do amerykańskiego wiceministra sprawiedliwości oznajmia że Departament będzie stosował odtąd w tej dziedzinie zasady immunitetu ograniczonego (restrictive), uważając ją za zgodną z obowiązującym prawem międzynarodowym, w miejsce uprzedniej, opartej na doktrynie Sędziego Marshalla (z wyroku The Schooner Exchange v. McFaddon \& others) ${ }^{12}$. Przekonanie, iż l'Etat étranger ne jouit de l'immunité juridictionnelle que pour certains actes dits de puissance publique ${ }^{13}$, tzn. konstrukcja restryktywnego (lub relatywnego) immunitetu jurysdykcyjnego państwa uformowała się więc już w międzynarodowym prawie zwyczajowym.

${ }^{10}$ Choć wzrost obrotu międzynarodowego iure negotii był już oczywisty od końca XIX w., niewątpliwy znaczny wpływ na tę ewolucję miały konsekwencje Rewolucji Październikowej i wprowadzenia monopolu handlu zagranicznego przez państwo sowieckie.

${ }^{11}$ H. Grotius, De Jure belli ac pacis, Libri Tres, [w:] J. B. Scott (ed.), The Classics of International Law, Księga III, rozdz. XVI, sekcja XXIX, Oxford 1925, s. 428.

12 Zob. US Department of State Bulletin 26, 1952, s. 984-985: J. Tate mówi o concepts i theory immunitetu jurysdykcji, stwierdzając, że restrictive theory jest uznana w prawie (recognized) jako ograniczająca ten immunitet do acta iure imperii. Departament Stanu zaczął od tego czasu formułować tzw. suggestions of immunity dla sądów amerykańskich. Wreszcie przyjęty w $1976 \mathrm{r}$. Foreign Sovereign Immunities Act potwierdził kompetencje Departamentu Stanu w tej dziedzinie. Trzeba tu zauważyć, że proces uznania konceptu odbywa się w obrębie prawa materialnego, a nie procesowego, jak dotychczas. Zob. Restatement (Third) of the Foreign Relations Law of the United States, American Law Institute Publications 1987, vol. I; także G. Ress, The Changing Relationship Between State Immunity and Human Rights, [w:] M. da Salvia i M. E. Villiger (eds.), The Birth of European Human Rights, Liber Amicorum Carl Aage Norgaard, Baden-Baden, 1998; W. Habscheid, Die Staaten Immunität Erkenntnis und Vollstreckungsverfahren, [w:] W. Habscheid \& al. (eds.), Freiheit und Zwang, Festschrift zum 60. Geburtstag von Hans Giger, Bern 1989, s. 213.

13 J. F. Lalive, L'immunité de juridiction des états et des organisations internationales, [w:] RCADI 1953, vol. 84, t. III, s. 285; skądinąd autor uważa, że nie istnieje żadna norma zwyczajowa lub traktatowa nakazująca państwom uznanie immunitetu jurysdykcyjnego państwa w prawie międzynarodowym, ibidem, s. 251. 


\section{Kadr traktatowy}

Pierwszym tekstem, który zajmuje się immunitetem jurysdykcyjnym państwa jest rezolucja Instytutu Prawa Międzynarodowego z 1891 r. ${ }^{14}$ (oczywiście bez efektów traktatowych). Natomiast pierwszym traktatem tematycznym jest Konwencja w sprawie ujednolicenia zasad dotyczących immunitetu statków państwowych, zawarta w Brukseli (10 kwietnia 1926 r.) i Protokół Dodatkowy do niej z 19 maja 1934 r. Poza jasnym odróżnieniem statków funkcjonujących ex ius imperii, do których ogranicza się zakres immunitetu Konwencji, zawiera ona także klauzulę wzajemności (art. 6).

Konwencja Europejska zawarta w Bazylei w ramach Rady Europy reprezentuje następny, nader istotny etap prawa traktatowego dla ustalenia jego elementów normatywnych, niezależnie od jej zakresu formalnego obowiązywania ${ }^{15}$, przede wszystkim ze względu na poszukiwanie w niej synergii z ustawodawstwem i orzecznictwem prawa wewnętrznego.

Obie Konwencje powołują się na zwyczajowe pochodzenie restryktywnej konstrukcji immunitetu, opartej na rozróżnieniu aktów państwa iure imperii i iure negotii. Obydwie przyjmują za punkt wyjścia klasyczny koncept suwerenności państwa, a nie skutki podmiotowości międzynarodowej człowieka, które doprowadzają do sytuacji, szczególnie w relacji procesowej, w której osoba pozywająca państwo napotyka przeszkody z tytułu rewindykacji suwerennego immunitetu tego ostatniego. Jednak podejście procesowe do skutków immunitetu doprowadziło także - jak się wydaje - do umocowania zasady jego charakteru restryktywnego w wyniku „serii współzależnych prądów analizy prawnej”16.

Warto zauważyć, że autorzy Konwencji Bazylejskiej byli świadomi, iż chodzi tu nie tylko o międzynarodowy środek procesowy. Świadectwem tego jest Protokół Dodatkowy do tej Konwencji z 1972 r. powołujący Trybunał Europejski ds. Immunitetu Państwa z kompetencją materialną (a nie wyłącznie kasacyjną) do orzekania o sporach w sprawach interpretacji i stosowania Konwencji (kompetencja trybunału jest fakultatywna, jest on dostępny dla osób prywatnych, został utworzony 22 maja 1985 r., a jego funkcje są sprawowane przez ETPC (na zasadach przez niego ustanowionych) ${ }^{17}$.

${ }^{14}$ Projet de réglement international sur la competence des tribunaux dans le proces contre les Etats, souverains ou chefs d'Etat étrangers, (11 IX 1891), Session de Hamburg, szczególnie art. 4. i 5., [w:] Résolutions de l'Institut de Droit International 1873-1956, s. 14-16.

${ }_{15}$ Zob. tekst w A. Dickinson, R. Lindsay, J. Loonam, State Immunity: Selected Materials and Commentary, Oxford 2004, s. 1-9; np. Polska przystąpiła do Konwencji Brukselskiej 8 I 1936, wypowiedziała ją 17 III 1952 i przystąpiła do niej ponownie 16 VII 1976 r. Konwencję Bazylejską ratyfikowało tylko 7 państw, obecnie członków UE i Szwajcaria.

${ }^{16}$ Zob. H. Fox, op. cit., s. 41-99.

${ }_{17}$ P. Trooboff, Foreign State Immunity: Emerging Consensus on Principles, RCADI 1986, vol. 200, s. 266-268; także I. Pingel-Lenuzza, op. cit., s. 3. 
Dalszy rozwój prawa traktatowego dokonywał się w ramach przekazania Komisji Prawa Międzynarodowego zagadnienia immunitetu państwa do kodyfikacji, a więc w celu jego ogólnoprawnej, normatywnej instytucjonalizacji.

Już w czasach Ligi Narodów (1928) uważano to zagadnienie za dojrzałe do takiej kodyfikacji ${ }^{18}$, znajdowało się ono także pomiędzy czternastoma oryginalnymi przedmiotami do kodyfikacji w agendzie Komisji, która jednak dopiero w 1978 r. wpisała go na swoją wokandę ${ }^{19}$. Pierwszy Projekt artykułów o immunitetach jurysdykcyjnych Państw i ich dóbr został przyjęty w 1986 r., przedłożony rządom do obserwacji i sfinalizowany w 1991 r. wraz z rekomendacją zwołania rządowej konferencji kodyfikacyjnej. Projekt ten nie został jednak przyjęty przez ZO ONZ, które odesłało go do dalszego opracowania i komentarzy państw, powołując grupę roboczą VI Komisji w celu ich głębszego przestudiowania. Konsultacje trwały (w różnych gremiach, łącznie z ponownym odesłaniem projektu do KPM) przez następnych lat piętnaście, tak że dopiero w 2004 r. projekt został ostatecznie przyjęty przez ZO ONZ (2 grudnia 2004 r.) (Konwencja wchodzi w życie po trzydziestej ratyfikacji ${ }^{20}$.

Cały ten międzynarodowy proces legislacyjny, z jego trudnościami, meandrami procedury i powikłaniami politycznymi koncentrował się wokół definicji granic pojęcia suwerenności iure imperii (wraz z organicznie z tym związanym zagadnieniem stosowania egzekucji), rozróżnienie między ius imperii a ius gestionis - a więc restrykcja immunitetu absolutnego państwa - będąc od początku projektu powszechnie przyjęta.

Można więc twierdzić, że prawo traktatowe uznaje immunitet jurysdykcyjny państwa za:

a) funkcjonalnie ograniczony pod względem jego skutków;

b) relatywny pod kątem charakteru typu działalności państwa (iure imperii lub negotii);

c) posiadający charakter normatywno-materialny, a nie tylko procesowy; $i$

d) organicznie związany z pojęciem suwerenności państwa i jego interpretacjami.

Konfiguracja kadru traktatowego immunitetu byłaby niepełna, gdyby pominąć fakt, że ograniczanie zakresu suwerenności iure imperii dokonywało się w prawie międzynarodowym pod presją całej ewolucji związanej z rozwojem pozycji normatywnej człowieka jako pełnoprawnego podmiotu tego prawa i spowodowanych przez ten rozwój zmian w ładzie międzynarodowym (w sensie politycznym) i w jego normatywnym porządku (ordre public international). Traktaty praw

${ }^{18}$ Zob. Additional Protocol to the European Convention on State Immunity, [w:] A. Dickinson, R. Lindsay, J. Loonam, op. cit., s. 31-36 i komentarz do Konwencji i Protokołu, s. 37-70; zob. I. Pingel-Lenuzza, op. cit., s. 256.

19 Zob. Rezolucja ZO ONZ 32/151 z 19 XII 1977 I ACDI, 1978, vol. II, s.169-171.

20 Zob. La Commission du Droit International et son æuvre, ONU, New York 2005, wyd. 6, vol. II, s. 177-186; zob. Rezolucja ZO ONZ 59/38 z 2 XII 2004. 
człowieka odegrały bez wątpienia w tym procesie kluczową rolę, ale - choć nie należy to stricto sensu do tematu naszej dyskusji - nie sposób pominąć wpływu, jaki wywarł na konstrukcję immunitetu państwa rozwój międzynarodowego systemu sankcji karnej dla państwa i jego organów oraz jego konsekwencje we współczesnym zakresie odpowiedzialności państw ${ }^{21}$. Wychodząc z przepisów normatywnych prawa humanitarnego, rozwijał się on ku radykalnej przebudowie obszaru „odpowiedzialności państwa $\mathrm{w}$ prawie międzynarodowym, by poprzez rozwój praw człowieka doprowadzić do ustaleń traktatowych, sfinalizowanych w Statucie Rzymskim z 17 lipca 1998 r. Mimo że proces ten nie należy bezpośrednio do głównego nurtu określania treści normatywnej immunitetu jurysdykcji, jego wpływ jest istotną częścią kadru traktatowego tego immunitetu (dotyczy to również de maiori ad minus traktatów poprzedzających zasady normatywy Statutu Rzymskiego - takich jak Konwencje Haskie z 1899 i 1907, Konwencje Genewskie etc.).

Kontrowersja co do natury, zakresu i funkcji normatywnej tego procesu znajduje się w centrum debaty o roli i funkcji całego prawa międzynarodowego; ,,...) this is hardly a surprise since the classic Westphalian model of international society was constructed precisely in order to minimize the opportunities for States to be legitimately (podkr. C. S.) interested in questions concerning the treatment by the State of its own nationals (...) this is quite obvious from the conceptualization of an entire body of substantive law concerning the treatment of aliens abroad. International law has traditionally (podkr. C. S.) been all about boundaries ${ }^{22}$ ".

Nie ma tu żadnego powodu do zdziwienia wobec tendencji przeobrażeń normatywnych spowodowanych pełnoprawną podmiotowością człowieka ani też wobec frontalnej ofensywy adwersarzy wartości i wpływu traktatów prawnoczłowieczych w formowaniu ogólnych konstrukcji prawa międzynarodowego, a więc tego że: „,...) the Court must take into account any relevant rules of international law (podkr. C. S.) when examining questions concerning its jurisdiction and, consequently determining State responsibility in conformity with the governing principles of international law, although must remain mindful of the Conventions special character as human rights treaty"23.

${ }_{21}$ T. Rensmann, Staaten-Immunität und Volkerrechtwidrige Hoheitsakte, Praxis des Internationalen Privat - Verfahrensrechts 1998, vol. 18, s. 44-48; w odniesieniu do prawa humanitarnego R. Provost, International Human Rights and Humanitarian Law, Cambridge, 2002, s. 43-50; zasadniczy związek normatywny w rozwoju tzw. międzynarodowego prawa karnego z tematem immunitetu zasadza się w tym, że ,...) on intending to elude the question, the treatment dispensed to the central chapter of the law of international responsibility of the State will keep on juridically unconvincing and conceptually incomplete (...) postponing the construction and consolidation of true role of law (...) and (...) of the right to law" (podkr. C. S.); A. A. Cançado Trindade, International Law for Humankind, Leiden, Boston 2010, s. 390.

${ }_{22}^{2}$ M. D. Evans, State Responsibility and the European Convention on Human Rights: Role and Realm, [w:] M. Fitzmaurice, D. Sarooshi (eds.), Issues of State Responsibility before International Judicial Institutions, Oxford 2004, s. 140-160.

${ }^{23}$ ETPC, Bankovic v. Belgii \& others (GC), decyzja z dnia 12 grudnia 2001 r., pkt 57. 


\section{Kadr jurysprudencyjno-doktrynalny}

Uwagi co do kontrowersji wokół wpływu praw człowieka na uregulowania traktatowe prowadzą do kilku obserwacji o wpływie orzecznictwa i doktryny na konceptualizację normatywną immunitetu jurysdykcyjnego. Coraz częściej obecnie wyprowadzanie ogólnych konceptów prawa międzynarodowego odbywa się drogą poszukiwania ich zakresu i substancji w orzecznictwie międzynarodowym. W aktualnej strukturze społeczności międzynarodowej, przy wzroście ilości i kompetencji międzynarodowych organów sądowych jest to normalne, jeśli nie nieuniknione. Niemniej niezależnie od formalnej dogmatyki źródeł prawa międzynarodowego (art. 38 Statutu MTS), trzeba pamiętać, że tak jurysprudencja jak i doktryna mają za główne zadanie stosowanie i interpretację prawa międzynarodowego jako uformowanego lex lata. Nie ulega wątpliwości, że oba te, formalnie subsydiarne, źródła uczestniczą dziś, merytorycznie i w żwawo wzrastający sposób, w konstrukcji i dynamice rozwoju prawa międzynarodowego, a więc w definicji treści normatywnej współczesnego międzynarodowego ordre public ${ }^{24}$.

W przypadku definicji immunitetu jurysdykcyjnego państwa, rola ta jest ważna i wyraźna. Niemniej nawet wybiórczy przegląd orzecznictwa międzynarodowego w ramach naszego spotkania wydaje się zbędny wobec bogactwa programu Konferencji w tym zakresie ${ }^{25}$. Ograniczę się zatem do kilku uwag dotyczących pewnych aspektów sądowej metody konstruowania zawartości i zakresu immunitetu.

Pierwsza odnosi się do różnic między strukturalnym i systemicznym podejściem krajowych porządków prawnych do zasięgu skutków immunitetu jurysdykcyjnego państwa i odpowiednich pozycji procesowych jednostki. Miejsce i wpływ prawa międzynarodowego tak w porządku konstytucyjno-ustawodawczym państwa, jak i w jego rozumieniu i używaniu przez wewnętrzne organy sądownicze i administracyjne ${ }^{26}$ oraz różnorodność europejskich systemów prawnych

${ }^{24}$ Zob. inter alia uwagi A. A. Cançado Trindade, op. cit., s. 123-126; „(...) judicial decisions as source of international law are bound to increase its importance (...)”, ibidem, s. 124; i dalej „European and Inter-American Court of Human Rights (...) have indeed contributed to the creation of an international ,ordre public" based upon the respect of human rights (...). They both helped to achieve the aptitude of international law to regulate efficiently relations (...) opposing States to individuals (...)", passim, s. 124.

${ }^{25}$ Zob. inter alia referaty dr. M. Balcerzaka, dr. I. Kamińskiego, mec. R. Nowosielskiego oraz komunikaty dr E. Salkiewicz-Munnerlyn i dr K. Wierczyńskiej w niniejszej publikacji.

${ }_{26}$ Zob. np. H. Suchocka, Aktualne zagrożenia dla realizacji praw człowieka $w$ Polsce, [w:] R. Wieruszewski, R. Hliwa (red.), Międzynarodowe Pakty Praw Człowieka standard prawny i jego realizacja, Poznań 2002. „Nie jest zatem wystarczające przeniesienie (...) formalnie określonej instytucji do danego porządku prawnego, aby ona skutecznie funkcjonowała, ale trzeba także odpowiednio do tego zmienić niejako otoczenie czasami prawne, a czasami, co wydaje się znacznie trudniejsze, faktyczne i mentalnościowe, aby dana instytucja spełniała pozytywną rolę i rzeczywiście gwarantowała, zapewniała realizację prawa" (podkr. C. S.), ibidem, s. 47, także uwagi w dyskusji C. Swinarski, ibidem, s. 75-76. 
mogą być powodem nie zawsze spójnego traktowania zagadnienia immunitetu przez organy krajowe nim trafią one przed Trybunał strasburski.

Trudniej może spostrzegalnym, lecz istotnym aspektem jest ,ideologia” sędziów, gdy idzie o koncept suwerenności w pojmowaniu norm prawa człowieka w procesie adekwatnej harmonizacji obu wartości w danym orzeczeniu, a cóż dopiero w całym orzecznictwie ${ }^{27}$. System selekcji sędziów ETPC nie daje pełnych gwarancji, że te funkcjonalne, a czasem metaprawne aspekty, nie przeniosą się na strasburskie forum, odzwierciedlając się $\mathrm{w}$ jego jurysprudencji.

Wymienić tu jeszcze można problemy wynikające $\mathrm{z}$ ewentualnych różnic między orzecznictwem międzynarodowym, amerykańskim (IACHR) i europejskim (ETPC), a także między każdym z nich, i orzecznictwem MTS, które również mogą przyczyniać się do niespójności normatywnej konstrukcji tego immunitetu ${ }^{28}$.

Instytucjonalizacja normatywna immunitetu - jak w niewielu innych dziedzinach prawa międzynarodowego - znajduje się na czułym ,styku” między pragmatycznym zaangażowaniem prawa wewnętrznego w zapewnienie najlepszej ochrony swego ładu prawnego a wzrastającym wpływem - żeby nie powiedzieć stałą presją - prawa międzynarodowego na ten ład. Nie należy się więc zbytnio dziwić kontrowersjom i niespójnościom wynikającym w procesie konceptualizacji konstrukcji międzynarodowej immunitetu jurysdykcyjnego w jurysprudencji jako uprzywilejowanego źródła, gdzie ostatecznym, nie zawsze wspólnym punktem wyjścia pozostaje definicja normatywna suwerenności państwa.

Na tym etapie uwag można twierdzić, że w świetle źródeł prawa międzynarodowego proces konceptualizacji osiągnął poziom, na którym immunitet jurysdykcyjny państwa można scharakteryzować jako konstrukcję współczesnego prawa wytworzoną w celu właściwego funkcjonowania, na warunkach określonych przez obowiązujące przepisy międzynarodowego porządku publicznego (ordre public); jest ona:

- funkcjonalna, jako instrument działania tego porządku,

- efektywna, bo pełnoprawnie obowiązująca i skutkująca,

- relatywna, bo zależna od interpretacji innych norm prawa międzynarodowego i

- restrykcyjna w odniesieniu do wykonywania przez państwo uprawnień suwerenności.

${ }^{27}$ Zob. np. uwagi M. Koskenniemi, The Ideology of International Adjudication and the 1907 Hague. Conference, [w:] Y. Daudet (ed.), Topicality of the 1907 Hague Conference, the Second Peace Conference, Leiden, London 2008, ,....) if international adjudication still sounds like 'ideology' this is not necessarily pejorative but indicates the close relationship of that institutional project to a number of associated ideas about the nature of the international political world (...)".

${ }_{28}$ Zob. A. A. Cançado Trindade, op. cit.; Autor uważa, że poza ich pełnym udziałem w konstytucji „ordre public”, ibidem, s. 588, „(...) permissible restrictions (limitations and derogations) to the exercise are to be restrictively interpreted", passim, note 76. Zob. również szerzej A. A. Cançado Trindade, Approximations and Convergences in the Case-Law of the European and Inter-American Courts of Human Rights, [w:] G. Cohen-Jonathan, J.-F. Flauss (eds.), Le rayonnement international de la jurisprudence de la Cour européenne des droits de l'homme, Bruxelles 2005, s. 101-138. 


\section{Kadr hermeneutyczno-instytucjonalny}

Taka strategiczna pozycja immunitetu jurysdykcyjnego w normatywnej topografii dzisiejszego prawa międzynarodowego ściśle wiąże jej profil z ogólną debatą o strukturze i funkcjach prawa w stosunkach międzynarodowych. Jak wiadomo kształtują się w tej debacie trzy stanowiska (approaches):

- stanowisko „unitarne” głoszące jedność (unity, unicité), tzn. istnienie jednego, powszechnego systemu normatywnego zawierającego wszystkie obowiązujące normy regulujące społeczność międzynarodową (z różną mocą i zakresem obowiązywania przez rozróżnienia między hard law i soft law lub norm regionalnych od uniwersalnych) $)^{29}$

- stanowisko „pluralistyczne”, dla którego stosunki międzynarodowe rządzą się różnymi zespołami norm rozmaitego pochodzenia i mocy obowiązywania ${ }^{30}$;

- stanowisko „fragmentarystyczne”, oparte na tezie, że obok ogólnego systemu normatywnego prawa międzynarodowego, istnieją podsystemy specyficznie z tym prawem związane, ale zawierające - każdy z nich - właściwe sobie zasady i rozwiązania normatywne ${ }^{31}$.

Pojęcie międzynarodowego porządku prawnego, jego treści normatywnej i współczynników jego dynamiki umiejscawiają się bardzo różnie dla protagonistów i przeciwników takiego czy innego stanowiska, wpływając w istotny sposób na praktykę i koncepcje pochodzenia źródeł prawa międzynarodowego ${ }^{32}$. Współzależność tej debaty teoretyczno-prawnej od procesów globalizacji i mondializacji

29 Zob. np. inter alia A. Zimmermann, R. Hofmann (eds.), Unity and Diversity in International Law, Berlin 2006; Ogólnie P. M. Dupuy, L'Unité de l'ordre juridique international, RCADI 2002, vol. 297.

${ }^{30}$ Zob. inter alia A. Fisher-Lescano, G. Teubner, Regime-Collisions: The Vain Search for Legal Unity in the Fragmentation of Global Law, „Michigan Journal of International Law” 2004, vol. 25, s. 999-1046; B. Simma, D. Pulkowski, Of Planets and the Universe: Self-Contained Regimes and the International Law, 17 EJIL 2006, s. 483-529; S. Ratner, Regulatory Takings in Institutional Context: Beyond the Fear of Fragmented International Law, 102 AJIL 2008, nr 3, s. 475-528; również M. Balcerzak, Międzynarodowa ochrona praw człowieka a pluralizm prawny - wybrane aspekty; M. Kałduński, Prawo międzynarodowe - fragmentacja systemu, [w:] D. Bunikowski, K. Dobrzeniecki (red.), Pluralizm prawny - tradycja, transformacje, wyzwania, Toruń 2009, odpowiednio s. 77-98 i 303-330.

31 Zob. Fragmentation of International Law: Difficulties Arising from Diversification and Expansion of International Law, Report of the Study Group of the International Law Commission finalized by M. Koskenniemi, UN Doc. A/CN/L.GP2 z 13 IV 2006 r. Najbardziej aktualny i kompletny przegląd implikacji normatywnych omawianej debaty (dalej: M. Koskenniemi, Report...).

32 Zob. M. Koskenniemi, General Principles and Equity: General principles: reflections on constructivist thinking in international law, [w:] M. Koskenniemi (ed.), Sources of International Law, Aldershot, Burlington, Singapore, Sydney 2000; zob. także R. Dworkin, Taking Rights Seriously, Cambridge 1977. 
stosunków międzynarodowych jest oczywista ${ }^{33}$. Każde ze stanowisk prowadzi do zróżnicowanych wniosków o pochodzeniu, zawartości i funkcji konstrukcji normatywnych prawa pozytywnego z nich wynikających.

Immunitet jurysdykcyjny państwa znajduje się par excellence $\mathrm{w}$ tematyce debaty nie tylko jako konstrukcja skutkująca na "styku” prawa wewnętrznego, ale także w obszarze różnych, mniej lub bardziej uformowanych „podsystemów” międzynarodowych, takich jak prawa człowieka i prawo europejskie, do których należą normy Europejskiej Konwencji Praw Człowieka.

Nie wchodząc tu w kwestię komponentów europejskiego systemu praw człowieka, na który składałyby się z kolei różne podsystemy normatywne (tzn. system Rady Europy, Wspólnot Europejskich i Konferencji Bezpieczeństwa i Współpracy w Europie) i który posiadałby własną autonomię funkcjonalną ${ }^{34}$, nie sposób w tych rozważaniach pominąc wpływu debaty na umiejscowienie na mapie normatywnej immunitetu jurysdykcyjnego państwa. Zasadniczym wydaje się tu być koncept międzynarodowego porządku publicznego, (ordre public) jako że miejsce na tej mapie konstrukcji immunitetu zależy przede wszystkim od odpowiedzi na dwa współzależne pytania, a mianowicie:

- czy prawo międzynarodowe zawiera osobny, specyficzny porządek praw człowieka, różny od porządku praw państwa (inter-state law)?

- czy prawo europejskie praw człowieka wypada uważać za autonomiczny (self-contained) podsystem międzynarodowy?

Koncept międzynarodowego porządku publicznego w prawie międzynarodowym (ordre public) kształtuje się w poszukiwaniu naczelnej jego racji bytu (ultimo ratio legis). Instytucjonalizacja praw człowieka w tym prawie definiuje - wraz z konceptami jus cogens i obowiązkami erga omnes - jego obecną funkcję normatywną ${ }^{35}$. Instytucjonalizacja ta określa zatem zakres pozytywnego prawa społeczności międzynarodowej ${ }^{36}$, który jest uważany za główny motor procesu ewolucji prawa międzynarodowego od stosunków wzajemności jego podmiotów w kierunku ,systemu opartego na interesie społeczności” i na obiektywnych

${ }^{33}$ Zob. inter alia P. S. Berman, The Globalization of International Law, Andershot 2005; także analiza R. Lipschutz, C. Fogel, Regulation for the Rest of Us? Global Civil Society and the Privatization of Transnational Regulation, [w:] R. B. Hall, T. Biersteker (eds.), The Emergence of Private Authority in Global Governance, Cambridge 2002, s. 115-140.

${ }_{34}$ Zob. np. C. Mik, Koncepcja normatywna europejskiego prawa praw człowieka, Toruń 1994, s. 178-180.

35 Zob. D. Evrigenis, Institutionalisation des droits de l'Homme et driont universel, [w:] Internationales Colloquium über Menschenrechte, Deutsche Gesellschaft für die Vereinten Nationen, Berlin 1966.

${ }^{36}$ Co do obligacji erga omnes można stwierdzić, iż ,(...) as it becomes accepted that individuals also have rights erga omnes and that obligations erga omnes are incumbent upon them, there remains no cogent reason for proceeding to the determination of the juridical consequences of those obligations on a strictly inter-state basis"; zob. A. A. Cançado Trindade, op. cit., s. 325. 
stosunkach normatywnych (,objective normative relationship”) ${ }^{37}$. Mimo dalej trwających sporów wokół tych konceptów, można dziś twierdzić, że uwarunkowały one istotnie praktykę międzynarodową, a koncept obowiązywania erga omnes już się w niej na dobre zakorzenił. Jeśli ogólny porządek społeczności międzynarodowej opiera się na uznaniu integralnego w nim pełnego uczestnictwa praw człowieka, negatywna odpowiedź na pierwsze pytanie potwierdza w tym porządku pełną jego podmiotowość na ogólnych zasadach prawa międzynarodowego, jak też wynikające z niej normatywne rozwiązania ${ }^{38}$.

W perspektywie systemu Konwencji Europejskiej uprawnienia człowieka w postępowaniu przeciw państwu w wyniku naruszenia jego praw odpowiadają obowiązkowi do ograniczenia zakresu zwolnienia od odpowiedzialności tego ostatniego już na pierwotnej zasadzie immunitetu jurysdykcyjnego (par in parem non habet iudicium). Inaczej zostałyby naruszone fundamentalne zasady całego prawa: zasada równości stron i zasada dobrej wiary ${ }^{39}$. W takim razie przejście od konstrukcji immunitetu absolutnego do immunitetu restryktywnego nie opiera się tylko na funkcjonalnym ograniczeniu protekcji suwerennego państwa w wyniku rozróżnienia ius imperium od ius gestionis, ale także wynika z podstaw ogólnego porządku prawnego gwarantujących równą protekcję wszystkim jego podmiotom.

Poszukiwanie odpowiedzi na drugie pytanie i jej konsekwencji dla charakteru normatywnego immunitetu jurysdykcyjnego, prowadzi do refleksji związanych z prawną definicją konceptu międzynarodowego podsystemu autonomicznego (,self-contained system”).

Otóż, system taki, poza ograniczeniami wynikającymi z norm iuris cogentis, nie powinien zawierać norm:

- odbiegających od uprawnień na korzyść stron trzecich, w tym jednostek i organów pozarządowych (non state);

- odbiegających od zobowiązań prawa ogólnego, jeśli są one natury „,erga omnes" i mają organiczny lub współzależny charakter, włącznie z takimi, co do których praktyka wytworzyła ,uzasadnione przekonanie że nie można ich uchylać" (legitimate expectation of non derogation);

- odbiegających od przepisów traktatów o charakterze prawa publicznego lub konstytucyjnych traktatów organizacji międzynarodowych ${ }^{40}$.

${ }^{37}$ Zob. T. Meron, International Law in the Age of Human Rights, RCADI 2003, vol. 301, s. 275 .

${ }_{38}$ Zob. inter alia Ch. Tomuschat, Die Internationale Gemeinschaft, Archiv des Völkerrechts (1995), vol. 33; A. Orakhelashvili, State Immunity and International Public Order, GYIL 2002, vol. 45, s. 227.

39 Zob. analiza R. Kolb, La maxime „, nemo ex propia turpitudine commodum capere potest” en droit international public, „Revue belge de droit international” 2006, s. 84 i nast.

${ }^{40}$ Zob. M. Koskeniemi, Report..., s. 83. 
Według tych kryteriów, wypada stwierdzić, że system Konwencji Europejskiej ,is not and has not been conceived as a self-contained regime, in the sense that recourse to general law would have been prevented". W stosunku do EKPC, konkluzja ta w znacznej mierze opiera się na przesłance, iż ,imposing disproportionate restrictions on the right to access to the court as embodied in art. 6(1) ${ }^{\prime 41}$ byłoby niezgodne z zasadami ogólnego prawa międzynarodowego, bowiem „,...) Just as the right of access to court is an inherent part of the fair trial guarantee in that article, so some restriction on access must likewise be regarded as inherent, an example being those limitations generally accepted by the community of nations as part of the State immunity (...)" (podkr. C. S.) ${ }^{42}$.

Warto zwrócić tu znów uwagę na podkreślenie materialnej (a nie tylko procesowej) natury immunitetu państwowego jako elementu rangi gwarancji prawidłowego procesu.

Nie wydaje się, że zachodzi potrzeba szczegółowej analizy innych stanowisk, by poprawnie ulokować konstrukcję normatywną immunitetu jurysdykcyjnego na mapie topograficznej prawa międzynarodowego.

Co do charakteru regionalnego systemu europejskiego ochrony praw człowieka $\mathrm{w}$ zakresie relacji do przepisów ogólnego prawa międzynarodowego, nie dotyczy on raczej „regionalnych wyzwań” (regional challenges) wynikających z relatywizmu kulturowego czy odrębnych tradycji prawnych, ale przede wszystkim efektywnej realizacji tych przepisów ((...) in terms of implementation). „This would mean understanding regional variety not in term of exceptions but of the varying, context - sensitive implementation and application of shared standards"43.

W odniesieniu do immunitetu jego „regionalny” charakter wypływałby więc bardziej z orzecznictwa ETPC i jego skutków niż z odrębnej konfiguracji normatywnej, choć można się zastanawiać, czy kontekst tego orzecznictwa rzeczywiście odpowiada równomiernie w stosunku do wszystkich państw, kryteriom regionalizmu prawnego, chociażby ze względu na różnorodność w unormowaniu i interpretacji funkcji immunitetu państwa w prawach wewnętrznych ${ }^{44}$.

${ }^{41}$ Zob. ibidem, s. 12. Także uwagi M. Kałduński, Pewne uwagi na temat sprawy Kadi w kontekście fragmentaryzacji prawa międzynarodowego, [w:] D. Bunikowski, K. Dobrzeniecki (red.), op. cit., s. 325-327.

${ }^{42}$ Zob. A. A. Cançado Trindade, op. cit., s. 126; szerzej A. de la Pradelle, Maîtres et doctrines $d u$ droit des gens, wyd. 2, Paris 1950.

${ }^{43}$ Zob. A. Hurrell, Power, Principles and Prudence: Protecting Human Rights in a Deeply Divided World, [w:] T. Dunner, N. J. Wheeler (eds.), Human Rights in Global Politics, Cambridge 1999, s. 294-297.

${ }^{44}$ Zob. O. Schindler, Regional International Law, [w:] R. Bernhardt (ed.), Encyclopedia of Public International Law, t. IV, Amsterdam 2000, s. 101-165; także uwagi T. Jasudowicz, Determinanty międzynarodowo chronionej substancji praw człowieka w systemie uniwersalnym $i$ europejskim, [w:] T. Jasudowicz, C. Mik, O prawach człowieka: W podwójną rocznicę paktów: Whotdzie A. Michalskiej, Toruń 1996, s. 87-114. 
Chociaż ujęcia hermeneutyczno-doktrynalne konstrukcji immunitetu mogą się wydawać drugorzędne w stosunku z dogmatycznym podejściem do źródeł prawa międzynarodowego (w sensie art. 38 Statutu MTS) wypada wziąć pod uwagę, że ,(...) while international judges and arbiters have remained aware of the self-limitations inherent to their functions and representatives of States have only and invariably beheld their own interests in rather uncompromising way - doctrine has retained its creative function". Co więcej ,....) It is to be bear in mind that doctrine is not limited to the teachings of individual authors but comprises the relevant work emanated from collegiate organs within international organizations (...) international academic institutions and associations (...)"45.

Wreszcie, poszukiwanie istotnych elementów dla wykształcenia się tej konstrukcji w obszarze kryteriów ex aequo et bono wydaje się bezprzedmiotowe ze względu na ich ograniczoną funkcję normatywną, a także dlatego że „(...) international tribunals have often joined references to a simultaneous invocation of custom, or of treaties, or of general principles of law or of earlier judicial and arbitral decisions" ${ }^{\prime 4}$, także ich rola ogranicza się do odpowiedniej adaptacji orzecznictwa do okoliczności konkretnego przypadku.

\section{Propozycja konkluzji}

Taki, z natury rzeczy pobieżny przegląd powstawania i rozwoju konstrukcji immunitetu jurysdykcyjnego wydaje się pozwalać jednak na ogólne określenie granic jej miejsca (,topos”), jej natury i funkcji normatywnych na mapie współczesnego prawa międzynarodowego:

- Jest ona tam organicznie związana z konceptem suwerenności państwa, tzn. z jego przesłankami, rolą i skutkowaniem w ogólnym zakresie prawa, jako jeden z najistotniejszych paradygmatów;

- Niezależnie od swej funkcji procesowej konstrukcja ta posiada własną, prawnomiędzynarodową treść materialną, jako normatywna zasada regulacyjna w harmonizacji tego prawa ${ }^{47}$;

- Treść ta wykształciła się już w prawie zwyczajowym, została utwierdzona przez traktaty i potwierdzona w orzecznictwie i doktrynie, niezależnie, choć niewątpliwie w związku z jej zawartością normatywną w prawach wewnętrznych;

45 A. A. Cançado Trindade, op. cit., s. 126.

${ }^{46}$ Ibidem, s. 127; Ch. De Visscher, De l'équité dans le règlement arbitral ou judiciaire des litiges en droit international public, Paris, 1972, s. 9; szerzej zob. M. Akehurst, Equity and General Principles, ICLQ 1976, vol. 25, s. 801-813.

${ }^{47}$ Zob. Aneks do M. Koskenniemi, Report..., Dok A/CN4/L.682/Add. I pkt. 43, „(...) Irrespective of the special status or the designation (,fundamental”) enjoyed by some norms (...) conflicts between rules of international law should be resolved in accordance with the principle of harmonization (...) [and] interpreted as compatible to extent possible", s. 15. 
- Obecne miejsce topograficzne tej konstrukcji jest uwarunkowane-żeby nie powiedzieć uzależnione - od umiejscowienia podstawowych pojęć organizujących corpus iuris prawa międzynarodowego, i w pierwszym rzędzie od uwzględnienia pełnej podmiotowości człowieka w międzynarodowym porządku publicznym („ordre public”) wraz z uznaniem w nim mocy obowiązującej norm iuris cogentis i erga omnes jako podstaw tego konceptu;

- Jej ewolucja w porządku prawnym nie tylko potwierdza i umacnia takie umiejscowienie, ale nadaje jej podstawowe znaczenie jako nieodzownemu korelatowi tego porządku, precyzując, obok jego naczelnych i fundamentalnych zasad (takich jak zasada równości czy zasada dobrej wiary) jego modus operandi, jako taką można zaliczyć do ogólnych zasad prawa międzynarodowego ${ }^{48}$;

- Pojmowana jako zasada autonomiczna powszechnego prawa międzynarodowego, jej ewentualnie rozbieżne artykulacje w różnych podsystemach międzynarodowych wynikają ze specyficznych dla nich wymogów efektywnej implementacji ${ }^{49}$.

Wydaje się więc, że immunitet jurysdykcyjny państwa w kontekście Europejskiej Konwencji Praw Człowieka jest uregulowany normami powszechnego prawa międzynarodowego na ogólnych warunkach obowiązujących przepisów tego prawa tak, aby zapewnić odpowiednią ochronę wszystkim jego podmiotom.

Krytyka i zastrzeżenia przeciwników takiego ujęcia profilu normatywnego konstrukcji zasadza się $\mathrm{z}$ reguły $\mathrm{w}$ argumentacji w obronie tradycyjnego konceptu suwerenności państwa, przed mniej lub bardziej rzeczywistymi zagrożeniami ze strony heterodoksyjnych „barbarzyńców”, których chyba „(...) nie ma już na granicy" 50 .

${ }^{48}$ Zob. Deklaracja Zasad Prawa Międzynarodowego Dotyczących Przyjaznych Stosunków i Współdziałania Państw zgodnie z Kartą Narodów Zjednoczonych (rezolucja ZO ONZ 2625, XXV z 24 X 1970 roku), szczególnie zasada siódma: ,good faith in compliance with international obligations". Zob. także G. Fitzmaurice, The General Principles of International Law Considered from the Standpoint of the Rule of Law, RCADI 1957, s. 1-223; co do zasady dobrej wiary sub specie: „The principle of the duty of international cooperation is indeed related to that of bona fides, one can in fact find express support in international case-law for the principle of the duty of international cooperation in good faith. Principles of international law constitute altogether the pillars of international legal system itself'. - A. A. Cançado Trindade, International Law..., s. 79-80; zob. także Dissenting Opinion of Judge A. A. Cançado Trindade w sprawie: Jurisdictional Immunities of the States (Germany v. Italy), ICJ, 6 VII 2010 r, pkt. 124-153. „States may if they so wish, waive claims as to their own rights. But they cannot waive claims for reparation of rights (...) that are not theirs. Any purported waiver to this effect would be against the international „ordre public”, is a breach of jus cogens", pkt 178.

49 Zob. Aneks do M. Koskenniemi, Report..., par. 9: „The application of the special law does not normally extinguish the relevant general law which will remain valid and applicable".

${ }^{50}$ Zob. motto supra. 